\title{
Fetal Biometry: Is it Same in African Population? Are There Racial Differences?
}

\author{
Afrika Popülasyonunda Fetal Biyometrik Ölçümler Aynı mı? Etnik Farklıık \\ Var midır?
}

\author{
๑ Özer Birge, ๑ Mehmet Sait Bakır* \\ Somali Turkey Recep Tayyip Erdoğan Training and Research Hospital, Clinic of Gynaecology and Obstetrics, Mogadishu, Somali \\ *Akdeniz University Faculty of Medicine, Department of Gyneacologic Oncology, Antalya, Turkey
}

\section{Abstract}

Aim: Our study aims to investigate whether there is a difference between the African pregnant population at 14-42 weeks of gestation and standard ultrasonographic fetal biometric measurements.

Methods: This study was carried out at Mogadishu Somali Turkey Recep Tayyip Erdoğan Training and Research Hospital, Hodan District, Mogadishu, Somalia from July 2018 to September 2018. Four hundred and eighty-six females at 14-42 weeks' gestation were evaluated. Obstetrical ultrasound was done using a 3.5 MHz convex transducer on Toshiba Aplio XG Ssa-790a. Biparietal diameter (BPD), head circumference (HC), femur length (FL), and abdominal circumference (AC) were identified and measured.

Results: The median maternal age in the study sample was 26 years with the mode value of 30 years. The highest number of participants were in 38 weeks $(31,6.4 \%)$ and the lowest number of participants were in weeks 15 and 18 with 1 in each (0.2\%). BPD gradually increased from a minimum of $26.0 \mathrm{~mm}$ at week 14 to a maximum of $95.9 \mathrm{~mm}$. HC gradually increased from a minimum of $101.1 \mathrm{~mm}$ at week 14 to a maximum of $95.9 \mathrm{~mm}$ at week 42. AC increased gradually from a minimum of 76.6 $\mathrm{mm}$ at week 14 to a maximum of $369.2 \mathrm{~mm}$ at week 42. FL increased gradually from a minimum of $15.0 \mathrm{~mm}$ at week 14 to a maximum of $79.1 \mathrm{~mm}$ at week 42 .

Conclusion: The frequently used parameters of fetal biometry along with ultrasonographic appearance and measurements in our local population are in agreement with international studies except for HC which was lower than the Hadlock's measurement by an average of $7.8 \mathrm{~mm}$.

Keywords: Fetal biometry, biparietal diameter, head circumference, femur length, abdominal circumference, African population, ethnicity
Amaç: 14-42 gebelik haftasındaki Afrikalı gebe popülasyonu ile standart ultrasonografik fetal biyometrik ölçümler arasındaki farkı araştırmaktır.

Yöntemler: Bu çalışma Somali Hodan Eyaleti Mogadişu'daki, Somali-Türkiye Eğitim ve Araştırma Hastanesi'nde Temmuz ve Eylül 2018 ayları arasında yapıldı. Gestasyonel haftası 14-42 arasında olan 486 hamile kadın muayene edildi. 3,5 MHz probu olan Toshiba Aplio XG Ssa-790a marka obstetrik usg cihazı kullanıldı. Bipariatal çap (BPD), baş çevresi (HC), femur uzunluğu $(\mathrm{FL})$ ve karın çevresi $(\mathrm{AC})$ tanımlanıp ölçüldü.

Bulgular: Çalışma örneğinin maternal ortalama yaşı 26 yıl idi. Ortanca yaş 26, mod yaşı 30 idi. En yüksek katılımcı sayısı 38 haftada 31 kişi $(\% 6,4)$, en düşük katılımcı sayısı 15 ve 18. haftalarda 1 kişi $(\% 0,2)$ idi. BPD ölçümleri sırasıyla 14 . haftada minimum 26,0 mm'den maksimum 95,9 mm aralığında ölçüldü. HC ölçümleri sırasıyla 14. haftada minimum 101,1 mm'den maksimum 95,9 mm aralığında ölçüldü. AC 14. haftada minimum 76,6 mm'den 42. haftada maksimum 369,2 mm'ye kadar ölçümlerin olduğu görüldü. FL 14. haftada minimum 15,0 mm'den maksimum 79,1 mm'ye 42. haftada ölçüldü.

Sonuç: Bizim ölçüm yaptığımız lokal popülasyonda sık kullanılan fetal biyometrik ölçümler uluslararası çalışmalarla uyumlu görülürken, sadece Hadlock'un HC ölçümlerine göre ortalama olan 7,8 mm den küçük ölçüldü.

Anahtar Sözcükler: Fetal biyometrik, bipariatal çap, baş çevresi, femur uzunluğu, karın çevresi, Afrika popülasyonu, etnisite
Address for Correspondence/Yazışma Adresi: Özer Birge, Somali Turkey Recep Tayyip Erdoğan Training and Research Hospital, Clinic of Gynaecology and Obstetrics, Mogadishu, Somali Phone: +24 9961847056 E-mail: ozbirge@gmail.com ORCID: orcid.org/0000-0002-1939-3743 Received/Geliş Tarihi: 30 January 2020 Accepted/Kabul Tarihi: 08 July 2020
${ }^{\circ}$ Copyright 2020 by The Medical Bulletin of istanbul Haseki Training and Research Hospital The Medical Bulletin of Haseki published by Galenos Yayınevi. ๑Telif Hakkı 2020 Istanbul Haseki Eğitim ve Araştırma Hastanesi Haseki Tıp Bülteni, Galenos Yayınevi tarafından yayınlanmıştır. 


\section{Introduction}

With the introduction of obstetric ultrasonography (USG) in the early 1970s, it has been the most widely used method of fetal weight estimation. So many estimation models are evaluated. These models are based on evaluating fetal measurements. However, fetal growth differs by race/ethnicity, environment, and area. It is hard to apply an estimated fetal weight model made for a community to other communities. Thus, most researchers suggest analysing suitability of the model for that community before its clinical use. They also suggest that data specific for each community should be used, especially in undeveloped countries (1-4).

\section{Methods}

This was a prospective cross-sectional study carried out in Mogadishu, the capital city of Somalia. All pregnant mothers at 14-42 weeks' gestation and having a viable single baby who attended the obstetrics and gynecology outpatient clinic at Mogadishu Somali Turkey Recep Tayyip Erdoğan Training and Research Hospital from July 7, 2018, to September 5, 2018 were included in the study. Mothers with multiple gestations, mothers with less than 14 weeks of gestation, mothers with pregnancy complicated disorders (e.g. pre-eclampsia, bleeding), mothers with known fetal anomalies, pregnant women with concomitant disease possibly affecting fetal growth (e.g. diabetes mellitus, asthma, hypertension, renal disease, thyroid disease) were the exclusion criteria. Simple random sampling was used in this study. Data were collected using a specially made questionnaire. All the fetal biometry measurements were performed by the investigator using a Toshiba Aplio XG Ssa790a USG machine equipped with a $3.5 \mathrm{MHz}$ transducer. Fetal head measurements were made in an axial plane at the level where the continuous midline echo is broken by the cavum septum pellucidum in the anterior third and that includes the thalamus. This transverse section should demonstrate an oval symmetrical shape. Measurement of biparietal diameter (BPD) was from the outer edge of the closest temporomandibular bone to the outer edge of the opposite temporomandibular bone. Head circumference (HC) was measured around the calvarium from the same axial image as for the BPD. Abdominal circumference (AC) was measured through the transverse section of the fetal abdomen at the level of the stomach and bifurcation of the main portal vein into its right and left branches. Femur length (FL) was measured from the greater trochanter to the lateral condyle, with both ends clearly visible and at a horizontal angle $<450$. All measurements were expressed in millimeters. Estimated fetal weight was calculated in grams by the formulae described by Shepard and Filly, as these are included in the software of most commercially available USG scanners (5). To enable appropriate statistical comparison of data, only studies with the number of examined fetuses indicated were included since many studies do not indicate the number of fetuses and are reported in graphic rather than tabular forms.

The study was approved by the ethics committee of the hospital and before the inclusion of the patients, informed consent was obtained (Mogadishu Somalia Turkey Recep Tayyip Erdoğan Training and Research Hospital, date: 26.06.2018, decision no: 45).

\section{Statistical Analysis}

The data analyzed manually and then presented using tables and graphs which are designed in SPSS and Excel.

\section{Results}

The median maternal age of the study sample was 26 years (range: 16-43) with the mode value of 30 years.

The number of deliveries in the pregnant women was classified from 0 (primigravida/nullipara) to 16 (multipara) with multiparas constituting $77.8 \%$ of the participants who were scanned followed by nulliparas $22.2 \%$. This figure revealed that multiparas were the highest in number in the study sample (77.8\%). As the parity increased, the number of women who were scanned dropped. Again, it showed that there were women who delivered 16 times during their reproductive life.

The number of participants who did not know their last menstrual period (LMP) was 299 (61.5\%) and those who knew it was 187 (38.5\%). Due to this fact, most of the participants came to the clinic to find out their gestational age (GA).

Among participants in this study, the minimum GA was 14 weeks and the maximum was 42 weeks. The median GA was 29.9 weeks. Week 38 was the highest number of participants documented with $31(6.4 \%)$ followed by weeks 39 and 32 with 27 in each (5.6\%).

To the analysis of fetal biometric parameters;

The highest number of participants were in 38 weeks with $31(6.4 \%)$ and the lowest number of participants were in weeks 15 and 18 with 1 in each (0.2\%).

BPD measurements gradually increased from a minimum of $26.0 \mathrm{~mm}$ at week 14 to a maximum of 95.9 $\mathrm{mm}$ at week 42 as shown in Table 1. In comparison with Hadlock's study, we found out that there was a close relationship except in weeks 16-20; the mean BPD in this study was higher than in Hadlock's study. In the following weeks, it was almost the same mean BPD with fluctuation of $0.3 \mathrm{~mm}$ as shown in Figure 1.

$\mathrm{HC}$ measurements gradually increased from a minimum of $101.1 \mathrm{~mm}$ at week 14 to a maximum of $95.9 \mathrm{~mm}$ as shown in Table 2. In comparison with Hadlock's study and we found out that the mean $\mathrm{HC}$ in this was lower than 
in Hadlock's study starting from week 17 to week 42 as shown in Figure 2.

AC increased gradually from a minimum of $76.6 \mathrm{~mm}$ at week 14 to a maximum of $369.2 \mathrm{~mm}$ at week 42 as shown in Table 3. In comparison with Hadlock's study, we found out that the mean AC was higher in weeks 17-22 and weeks 33-42 and lower in weeks 23-32 (Figure 3).

FL increased gradually from a minimum of $15.0 \mathrm{~mm}$ at week 14 to a maximum of $79.1 \mathrm{~mm}$ at week 42 as shown in Table 4. In comparison with Hadlock's study, we found out that the mean FL was similar to that in Hadlock's study with $+0.2 /-0.2 \mathrm{~mm}$ differences between the studies (Figure 4).

\begin{tabular}{|c|c|c|c|c|c|}
\hline & & BPD & & & \\
\hline in WKS & participants & $(\mathrm{mm})$ & $5^{\text {th }}$ & $50^{\text {th }}$ & $95^{\text {th }}$ \\
\hline 14 to $14+6$ & 2 & 26.0 & 25.01 & 26.00 & 26.99 \\
\hline 15 to $15+6$ & 1 & 33.6 & 33.60 & 33.60 & 33.60 \\
\hline 16 to $16+6$ & 8 & 34.6 & 30.30 & 34.05 & 40.70 \\
\hline 17 to $17+6$ & 11 & 37.1 & 32.95 & 37.20 & 41.50 \\
\hline 18 to $18+6$ & 1 & 40.8 & 40.80 & 40.80 & 40.80 \\
\hline 19 to $19+6$ & 18 & 46.5 & 40.23 & 44.20 & 58.18 \\
\hline 20 to $20+6$ & 15 & 50.2 & 36.72 & 46.90 & 75.31 \\
\hline 21 to $21+6$ & 10 & 49.1 & 40.07 & 50.00 & 54.48 \\
\hline 22 to $22+6$ & 19 & 53.4 & 49.45 & 53.20 & 58.45 \\
\hline 23 to $23+6$ & 18 & 55.9 & 50.54 & 55.60 & 59.72 \\
\hline 24 to $24+6$ & 17 & 60.0 & 54.84 & 58.90 & 68.10 \\
\hline 25 to $25+6$ & 16 & 62.4 & 59.18 & 62.15 & 65.70 \\
\hline 26 to $26+6$ & 20 & 65.7 & 61.51 & 65.75 & 70.41 \\
\hline 27 to $27+6$ & 23 & 67.9 & 61.24 & 67.80 & 71.99 \\
\hline 28 to $28+6$ & 17 & 69.1 & 61.66 & 69.50 & 74.56 \\
\hline 29 to $29+6$ & 23 & 72.6 & 67.56 & 72.70 & 78.54 \\
\hline 30 to $30+6$ & 24 & 76.4 & 72.18 & 75.95 & 82.33 \\
\hline 31 to $31+6$ & 20 & 78.8 & 73.56 & 78.90 & 85.26 \\
\hline 32 to $32+6$ & 27 & 80.7 & 77.09 & 80.90 & 83.30 \\
\hline 33 to $33+6$ & 25 & 83.1 & 79.42 & 83.20 & 87.08 \\
\hline 34 to $34+6$ & 19 & 85.5 & 81.30 & 85.50 & 88.98 \\
\hline 35 to $35+6$ & 21 & 86.7 & 83.70 & 86.20 & 90.80 \\
\hline 36 to $36+6$ & 19 & 88.1 & 84.06 & 88.70 & 90.90 \\
\hline 37 to $37+6$ & 25 & 89.6 & 85.00 & 90.60 & 94.02 \\
\hline 38 to $38+6$ & 31 & 94.2 & 91.30 & 94.20 & 98.15 \\
\hline 39 to $39+6$ & 27 & 93.9 & 90.35 & 94.40 & 99.71 \\
\hline 40 to $40+6$ & 21 & 94.9 & 87.30 & 95.40 & 100.00 \\
\hline 41 to $41+6$ & 5 & 96.8 & 93.12 & 97.10 & 100.76 \\
\hline 42 to $42+6$ & 3 & 95.9 & 92.51 & 96.20 & 99.08 \\
\hline
\end{tabular}

\section{Discussion}

Sonographic estimation of GA, especially when based on the measurements of multiple fetal parameters and obtained under research conditions during the antepartum period, provides reliable and clinically useful information for most of the patients.

Since GA is still determined by LMP in some places, the chances of error increase, therefore, USG investigation is highly recommended as the only measuring tool for GA determination.

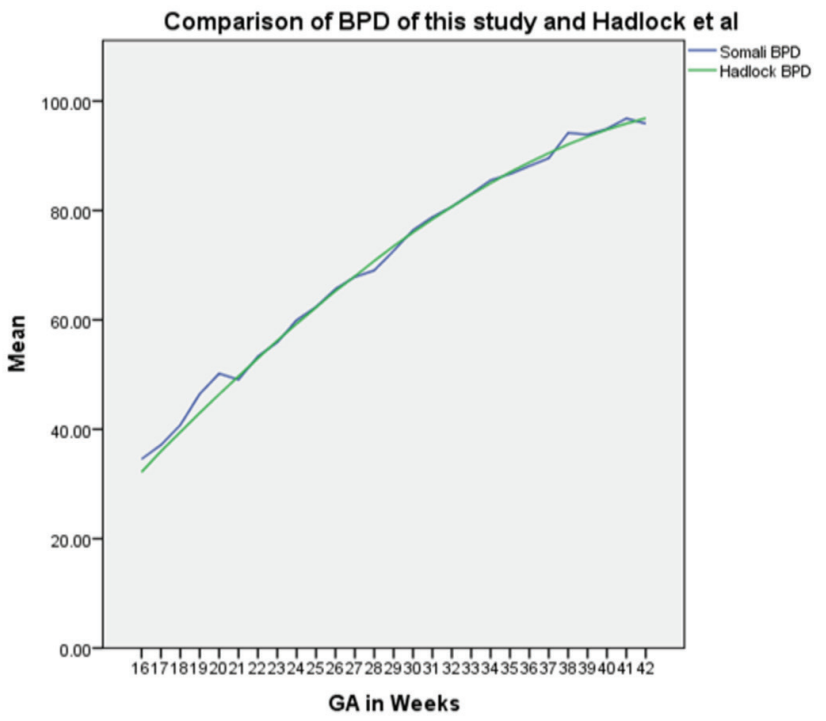

Figure 1. Line chart showing the comparison of BPD of this study and hadlocks

GA: Gestational age, BPD: Biparietal diameter

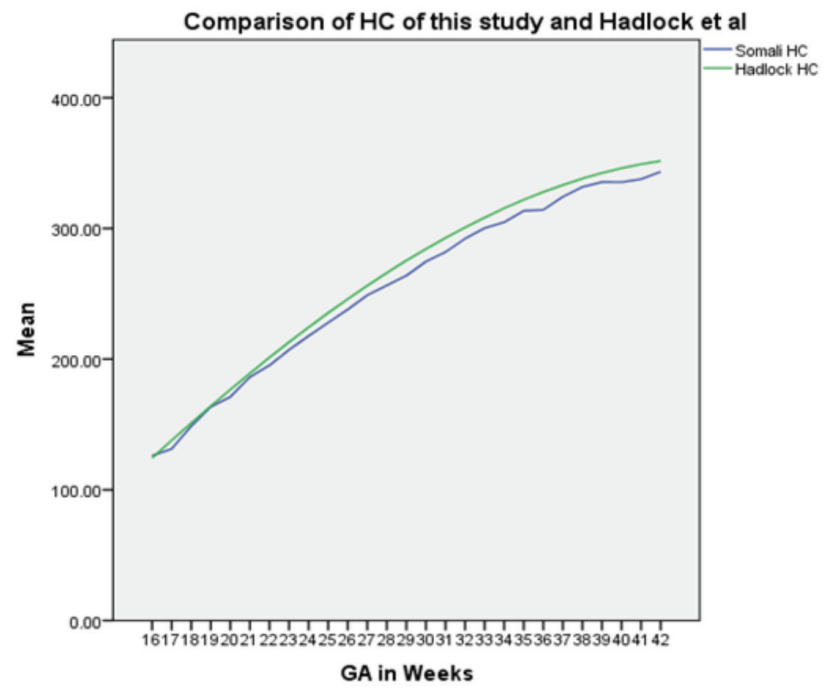

Figure 2. Line chart showing the comparison of $\mathrm{HC}$ of this study and hadlocks

GA: Gestational age, HC: Head circumference 
Also, since USG has pre-embedded equations to GA from the different fetal biometry measurements, there will be ethnic differences. Most of the USG machines have multiple equations based on different ethnicities that were collected by examining normal antepartum data from many participants. Each ethnicity has its own charts that correspond with their growth.

USG was first used to diagnose brain tumors and to measure the dimensions of the brain ventricles in 1942 by a neurologist, Dussik from Vienna (6). The possible existence of high frequency sounds which we can not hear was suggested by Spallanzini in 1974 after his

\begin{tabular}{|c|c|c|c|c|c|}
\hline \multirow[b]{2}{*}{ GA in WKS } & \multirow[b]{2}{*}{$\begin{array}{l}\text { No of } \\
\text { participants }\end{array}$} & \multirow[b]{2}{*}{$\begin{array}{l}\text { Mean HC } \\
(\mathrm{mm})\end{array}$} & \multicolumn{3}{|c|}{ Percentiles } \\
\hline & & & $5^{\text {th }}$ & $50^{\text {th }}$ & $95^{\text {th }}$ \\
\hline 14 to $14+6$ & 2 & 101.1 & 97.59 & 101.10 & 104.61 \\
\hline 15 to $15+6$ & 1 & 119.3 & 119.30 & 119.30 & 119.30 \\
\hline 16 to $16+6$ & 8 & 126.2 & 116.80 & 125.70 & 137.85 \\
\hline 17 to $17+6$ & 11 & 131.4 & 115.30 & 135.90 & 146.00 \\
\hline 18 to $18+6$ & 1 & 148.8 & 148.80 & 148.80 & 148.80 \\
\hline 19 to $19+6$ & 18 & 163.6 & 147.42 & 163.40 & 175.77 \\
\hline 20 to $20+6$ & 15 & 171.2 & 142.29 & 175.20 & 187.71 \\
\hline 21 to $21+6$ & 10 & 186.4 & 177.01 & 187.25 & 196.65 \\
\hline 22 to $22+6$ & 19 & 195.3 & 183.71 & 193.10 & 210.94 \\
\hline 23 to $23+6$ & 18 & 207.1 & 185.89 & 207.30 & 224.38 \\
\hline 24 to $24+6$ & 17 & 217.7 & 205.62 & 218.20 & 232.02 \\
\hline 25 to $25+6$ & 16 & 227.9 & 215.58 & 228.65 & 242.43 \\
\hline 26 to $26+6$ & 20 & 238.0 & 211.88 & 238.55 & 258.89 \\
\hline 27 to $27+6$ & 23 & 248.9 & 225.53 & 247.40 & 275.43 \\
\hline 28 to $28+6$ & 17 & 256.4 & 229.48 & 258.70 & 276.04 \\
\hline 29 to $29+6$ & 23 & 263.9 & 242.98 & 266.20 & 282.63 \\
\hline 30 to $30+6$ & 24 & 274.7 & 254.48 & 275.05 & 291.63 \\
\hline 31 to $31+6$ & 20 & 282.0 & 264.26 & 281.20 & 308.39 \\
\hline 32 to $32+6$ & 27 & 292.2 & 278.10 & 292.20 & 304.55 \\
\hline 33 to $33+6$ & 25 & 300.3 & 284.18 & 300.30 & 313.72 \\
\hline 34 to $34+6$ & 19 & 304.8 & 290.66 & 305.30 & 316.32 \\
\hline 35 to $35+6$ & 21 & 313.5 & 300.00 & 316.20 & 325.90 \\
\hline 36 to $36+6$ & 19 & 314.3 & 303.06 & 313.50 & 325.77 \\
\hline 37 to $37+6$ & 25 & 324.3 & 313.80 & 324.30 & 334.64 \\
\hline 38 to $38+6$ & 31 & 331.8 & 322.35 & 331.50 & 341.80 \\
\hline 39 to $39+6$ & 27 & 335.5 & 317.61 & 337.70 & 359.84 \\
\hline 40 to $40+6$ & 21 & 335.4 & 314.70 & 339.80 & 347.60 \\
\hline 41 to $41+6$ & 5 & 337.8 & 326.50 & 337.00 & 349.76 \\
\hline 42 to $42+6$ & 3 & 343.4 & 334.30 & 345.10 & 351.40 \\
\hline GA: Gestation & ge, WKS: W & $\mathrm{ks}, \mathrm{HC}: \mathrm{He}$ & cumfer & & \\
\hline
\end{tabular}

studies on bats. Piezoelectricity is found by Curries in 1880. Thirty-five years later, ultrasonic energy was first used. At the beginning of 1990s the basics of USG are found (7).

Currently available sonographic growth standards for fetal head size, abdominal size, and limb length are based primarily on studies from white populations. There is not much data from the black population in underdeveloped countries. To determine if these published standards are

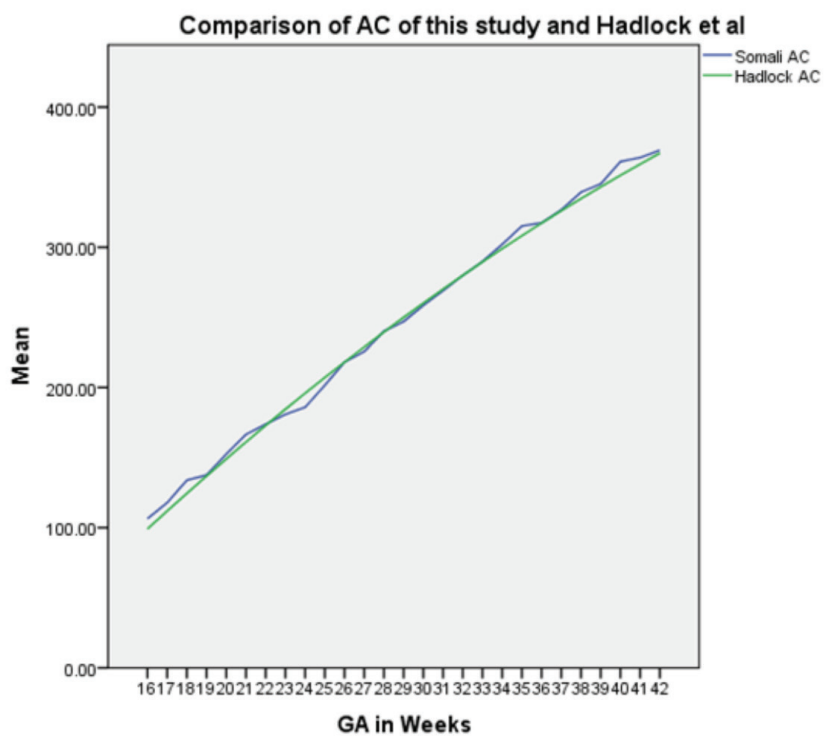

Figure 3. Line chart showing the comparison of $A C$ of this study and hadlocks

GA: Gestational age, AC: Abdominal circumference

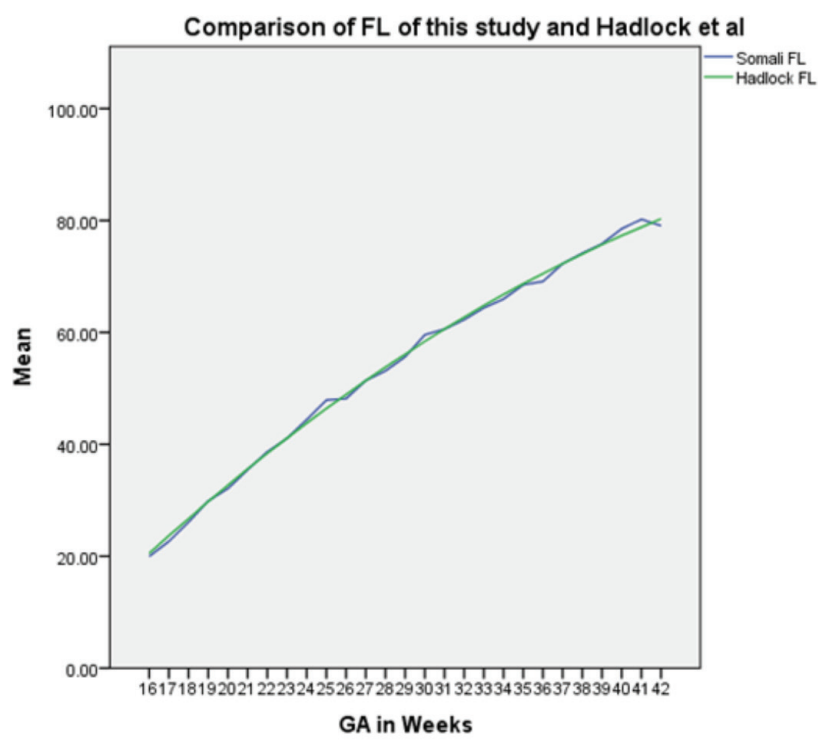

Figure 4. Line chart showing the comparison of FL of this study and hadlocks

GA: Gestational age, FL: Femur length 
appropriate for a racially mixed, indigent population. we compared our published data which is generated from a black African population examined at a training and research hospital in Mogadishu Somalia, with international Hadlocks USG data.

In their study investigating racial differences in humerus length, Mastrobattista et al. (8) found a difference between Asian and Afro-Americans at all GAs. When Caucasians and Afro-Americans were compared, it was observed that the humerus length of Afro-American fetuses were longer at all GAs. In addition, Caucasian fetuses had consistently longer humerus length than Asians.

\begin{tabular}{|c|c|c|c|c|c|}
\hline \multirow[b]{2}{*}{$\begin{array}{l}\text { GA } \\
\text { in WKS }\end{array}$} & \multirow{2}{*}{$\begin{array}{l}\text { No of } \\
\text { Participants }\end{array}$} & \multirow{2}{*}{$\begin{array}{l}\text { Mean } \\
\text { AC } \\
(\mathrm{mm})\end{array}$} & \multicolumn{3}{|c|}{ Percentiles } \\
\hline & & & $5^{\text {th }}$ & $50^{\text {th }}$ & $95^{\text {th }}$ \\
\hline 14 to $14+6$ & 2 & 76.6 & 73.36 & 76.60 & 79.84 \\
\hline 15 to $15+6$ & 1 & 101.3 & 101.30 & 101.30 & 101.30 \\
\hline 16 to $16+6$ & 8 & 106.5 & 102.00 & 105.20 & 112.68 \\
\hline 17 to $17+6$ & 11 & 117.8 & 109.10 & 119.90 & 127.10 \\
\hline 18 to $18+6$ & 1 & 133.9 & 133.90 & 133.90 & 133.90 \\
\hline 19 to $19+6$ & 18 & 137.5 & 125.42 & 138.90 & 146.32 \\
\hline 20 to $20+6$ & 15 & 152.5 & 135.07 & 150.20 & 171.42 \\
\hline 21 to $21+6$ & 10 & 166.5 & 156.10 & 163.10 & 183.45 \\
\hline 22 to $22+6$ & 19 & 173.7 & 162.25 & 174.10 & \begin{tabular}{|l|}
183.50 \\
\end{tabular} \\
\hline 23 to $23+6$ & 18 & 180.9 & 169.59 & 180.55 & 192.07 \\
\hline 24 to $24+6$ & 17 & 185.9 & 143.12 & 190.10 & 206.56 \\
\hline 25 to $25+6$ & 16 & 201.5 & 180.50 & 203.30 & 225.10 \\
\hline 26 to $26+6$ & 20 & 218.1 & 199.50 & 220.45 & 228.81 \\
\hline 27 to $27+6$ & 23 & 225.6 & 188.40 & 228.90 & 244.92 \\
\hline 28 to $28+6$ & 17 & 240.2 & 219.70 & 240.90 & 254.80 \\
\hline 29 to $29+6$ & 23 & 247.1 & 228.43 & 247.50 & 263.59 \\
\hline 30 to $30+6$ & 24 & 258.7 & 247.85 & 259.30 & 274.29 \\
\hline 31 to $31+6$ & 20 & 269.1 & 242.69 & 268.15 & 295.02 \\
\hline 32 to $32+6$ & 27 & 279.9 & 265.10 & 281.00 & 293.87 \\
\hline 33 to $33+6$ & 25 & 289.9 & 273.66 & 289.60 & 301.58 \\
\hline 34 to $34+6$ & 19 & 302.1 & 275.91 & 304.60 & \begin{tabular}{|l|}
317.49 \\
\end{tabular} \\
\hline 35 to $35+6$ & 21 & 315.2 & 300.90 & 312.70 & 345.30 \\
\hline 36 to $36+6$ & 19 & 317.4 & 296.98 & 321.90 & 328.55 \\
\hline 37 to $37+6$ & 25 & 326.8 & 314.84 & 327.00 & 339.46 \\
\hline 38 to $38+6$ & 31 & 339.3 & 322.85 & 337.20 & 364.85 \\
\hline 39 to $39+6$ & 27 & 345.2 & 331.42 & 345.00 & 371.38 \\
\hline 40 to $40+6$ & 21 & 361.2 & 341.40 & 361.10 & 378.50 \\
\hline 41 to $41+6$ & 5 & 364.0 & 346.18 & 359.90 & 383.90 \\
\hline 42 to $42+6$ & 3 & 369.2 & 367.28 & 368.00 & 371.96 \\
\hline GA: & 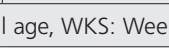 & c: & 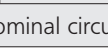 & 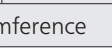 & \\
\hline
\end{tabular}

Hadlock at al. (9) examined the relation between $\mathrm{FL}$ and menstruation age and concluded that fetal FL could be used as an adjunct in estimating menstrual age. In Chitty and Altman's study, the femur and humerus measurements were longer for GA compared to that in our study (10). In our study, we used Hadlock's formula, so we did not measure humerus length. There was no difference in FL according to Hadlocks score.

In their study measuring fetal BPD by USG in 558 Nigerian women, Ayangade and Okonofua (11). reported a curve similar to those reported from Caucasian populations but with much less flexion in the later weeks

Table 4. Frequency distribution of fetuses scanned by femur length: frequency distribution table of fetal femur length measurements showing gestational age in weeks, number of participants, their mean and percentiles from 14-42 weeks gestation

\begin{tabular}{|c|c|c|c|c|c|}
\hline \multirow[b]{2}{*}{$\begin{array}{l}\text { GA } \\
\text { in WKS }\end{array}$} & \multirow[b]{2}{*}{$\begin{array}{l}\text { No of } \\
\text { Participants }\end{array}$} & \multirow{2}{*}{$\begin{array}{l}\text { Mean } \\
\text { FL } \\
(\mathrm{mm})\end{array}$} & \multicolumn{3}{|c|}{ Percentiles } \\
\hline & & & $5^{\text {th }}$ & $50^{\text {th }}$ & $95^{\text {th }}$ \\
\hline 14 to $14+6$ & 2 & 15.0 & 14.19 & 15.00 & 15.81 \\
\hline 15 to $15+6$ & 1 & 17.2 & 17.20 & 17.20 & 17.20 \\
\hline 16 to $16+6$ & 8 & 20.0 & 16.70 & 20.25 & 22.80 \\
\hline 17 to $17+6$ & 11 & 22.7 & 19.25 & 23.10 & 25.60 \\
\hline 18 to $18+6$ & 1 & 26.1 & 26.10 & 26.10 & 26.10 \\
\hline 19 to $19+6$ & 18 & 29.9 & 26.89 & 29.55 & 32.51 \\
\hline 20 to $20+6$ & 15 & 32.1 & 29.29 & 31.20 & 35.64 \\
\hline 21 to $21+6$ & 10 & 35.5 & 34.04 & 35.70 & 37.17 \\
\hline 22 to $22+6$ & 19 & 38.7 & 35.25 & 38.70 & 42.11 \\
\hline 23 to $23+6$ & 18 & 41.1 & 37.78 & 40.95 & 45.30 \\
\hline 24 to $24+6$ & 17 & 44.4 & 40.08 & 43.70 & 49.00 \\
\hline 25 to $25+6$ & 16 & 47.9 & 44.03 & 47.15 & 51.03 \\
\hline 26 to $26+6$ & 20 & 48.2 & 41.30 & 49.10 & 51.64 \\
\hline 27 to $27+6$ & 23 & 51.4 & 48.04 & 51.60 & 55.53 \\
\hline 28 to $28+6$ & 17 & 53.1 & 50.70 & 52.80 & 57.30 \\
\hline 29 to $29+6$ & 23 & 55.6 & 50.97 & 56.40 & 60.04 \\
\hline 30 to $30+6$ & 24 & 59.6 & 54.70 & 58.85 & 62.38 \\
\hline 31 to $31+6$ & 20 & 60.6 & 56.50 & 60.70 & 64.77 \\
\hline 32 to $32+6$ & 27 & 62.3 & 58.73 & 62.50 & 65.10 \\
\hline 33 to $33+6$ & 25 & 64.4 & 58.76 & 65.10 & 69.74 \\
\hline 34 to $34+6$ & 19 & 66.0 & 62.47 & 65.50 & 71.39 \\
\hline 35 to $35+6$ & 21 & 68.5 & 65.70 & 68.80 & 73.10 \\
\hline 36 to $36+6$ & 19 & 69.1 & 66.06 & 69.30 & 72.84 \\
\hline 37 to $37+6$ & 25 & 72.3 & 68.94 & 72.20 & 75.24 \\
\hline 38 to $38+6$ & 31 & 74.2 & 68.65 & 73.70 & 79.60 \\
\hline 39 to $39+6$ & 27 & 75.8 & 71.78 & 76.20 & 80.06 \\
\hline 40 to $40+6$ & 21 & 78.5 & 74.20 & 79.00 & 81.70 \\
\hline 41 to $41+6$ & 5 & 80.2 & 78.82 & 80.90 & 81.20 \\
\hline 42 to $42+6$ & 3 & 79.1 & 76.97 & 80.30 & 80.30 \\
\hline
\end{tabular}


of pregnancy. The BPD values per week were also lower in this study group. The reasons for these differences need to be discussed.

Muñoz et al. (12) reported that the smaller BPD in late pregnancy could be explained by the head's shape and concluded that new charts were valuable in assessing fetal growth in African blacks.

Van Bogaert (13) reported in their study from South Africa that there was no significant difference between customized gravidogram for African population and intrauterine fetal growth curve charts established for Caucasians.

Hadlock et al. (14) analyzed if the accuracy of fetal weight estimation increases with $\mathrm{FL}$ added to head and body parameters and developed an estimation model which is based on AC and FL when cephalometric measurements undoable. They found no statistically significant differences for any of the following fetal sonographic parameters (20 to 41 weeks): $n B P D, H C, A C$ and FL.

The HC was lower than in Hadlock's study. Variations in head size and brain volume are genetic and since the times of Galton, it has been customary to associate the size of the head (and size of the brain), as measured by $\mathrm{HC}$, with intelligence. Even the genes responsible for brain size (which is directly related to HC, cranial capacity, occipitofrontal diameter, etc.) have been identified even though they vary from one continent to another and require to be mapped out. Studies using brain imaging techniques such as magnetic resonance imaging reported that there was a $40 \%$ correlation between head size and intelligence quotient. Small brain size is said to be positively correlated with memory retention in old age and onset of dementia. It has also been shown that $\mathrm{HC}$ was strongly correlated with brain volume which presumably determines intelligence. Racial studies have shown a relationship between brain size and adult intelligence but we do not have enough data to determine what the situation of things is before birth which is different from what obtains after birth (14).

A Nigerian study provides extensive data for $\mathrm{HC}$ of 13,740 African (Nigerian) fetuses and suggests that early maturation of $\mathrm{HC}$ in African children vis-à-vis European, is a genetic rather than nutritional factor. Postnatal development, however, is probably dependent on nutrition and environment rather than gene. USG measurement of BPD in Nigerian fetuses showed a linear correlation between BPD and GA as well as BPD and fetal weight in normal fetuses (15).

In this study, particular attention was paid to the methodology used to construct these new ranges, doing our best to follow the recommendations made by the authors of previous methodological reviews (16-20). The
BPD values and centiles in this study were significantly lower than those in the Western population $(21,22)$. The only time that our values were significantly higher was from 15-16 weeks gestation. This finding is contrary to the one reported (23). This difference may be attributed to the claim that there is a systematic difference in the USG data sets collected before and after 1974, probably due to the differences that exist in the scanner resolutions before and after that period, and the later introduction of grayscale imaging (23).

The analytical method followed standard recommendations strictly. In the discussion, we classified the findings into maternal characteristics and fetal biometrics.

The study showed that, according to age group, higher number of participants $(51,10.5 \%)$ were aged 30 years and the least number of participants $(3,0.6 \%)$ were aged 40, 41 and 43 . The youngest was aged 16 years and the oldest was 43 years. The study also showed that according to parity, the highest number of participants were multiparas $(378,77.8 \%)$ followed by nulliparas (108, $22.2 \%)$. When the participants were asked about their LMP 299 (61.5\%) did not know it and 187 (38.5\%) knew their LMP.

\section{Study Limitations}

Before utilizing the results of this study with any pregnant woman, the following limitations must be noted:

1. The study population was selected from pregnant women who attended and had an USG scan at Mogadishu Somali Turkey Recep Tayyip Erdoğan Training and Research Hospital only. These women may not be representative of the general population.

2. A lot of rejections about the research have forced us to leave out many candidates with our limited time. Therefore, as health professionals, we must be gentle in convincing and potential participants incoming research and clear the misconceptions about any research in our community which has finished a civil war that devastated the country.

\section{Conclusion}

The study concludes that; further studies should examine and assess the HC of Somali fetuses and should use a large sample size to enable the generalization of the findings.

However at this level, we recommend consideration of the findings of this study to obstetricians practicing in Mogadishu, Somalia. To the obstetrician, normal values for the parameters of fetal BPD, HC, AC, and FL from Somali fetuses in Mogadishu between 14 and 42 weeks of gestation will be so useful such that the obstetrician who uses USG routinely in ante-natal care can screen for 
congenital anomalies in the fetus during the period of gestation using ratios of anthropometric measurement as described above in this environment.

We highly recommend awareness of LMP at the national level. As more than half of our participants did not know their LMP and it can be used to verify the GA determined by USG which currently uses an embedded equation from other ethnicities.

It can be used as a guideline for predicting GA fetal biometry measurements, in order to ascertain the degree of risk, to encourage mothers to improve their fetus's health and to come for follow-up.

It can be used for further studies in related fields.

The study has shown a detailed report of USG assessment of fetal biometry studies in Somali fetuses in Mogadishu using a very large sample size.

This study has identified that our HC was lower than in Hadlock's study while other parameters were closely related, which requires to be pursued by future investigators.

This study has provided a standard against which to compare size in individual fetuses in our environment.

\section{Authorship Contributions}

Concept: Ö.B., M.S.B. Design: Ö.B. Data Collection or Processing: Ö.B. Analysis or Interpretation: Ö.B., M.S.B. Literature Search: Ö.B., M.S.B. Writing: Ö.B., M.S.B.

Conflict of Interest: The authors declared no conflicts of interest concerning the authorship and publication of this article.

Financial Disclosure: The authors received no financial support for the research and/or authorship of this article.

\section{References}

1. Jordaan HVF. Estimation of fetal weight by ultrasound. J Clin Ultrasound 1983;11:59-66.

2. Hill LM, Breckle R, Gehrking WC, O'Brien PC. Use of femur length in estimation fetal weight. Am J Obstet Gynecol 1985;152(7 Pt 1):847-52.

3. Spinnato JA, Allen RD, Mendenhall HD. Birth weight prediction from remote ultrasound examination. Obstet Gynecol 1989;161:742-7

4. Thompson HO, Casaceli C, Woods JR. Ultrasonographic fetal weight estimation by an integrated computer-assisted system: Can each laboratory improve its accuracy? Am J Obstet Gynecol 1990:163:986-95.

5. Shepard M, Filly RA. A standardized plane for biparietal diameter measurement. J Ultrasound Med 1982;1:145-50.

6. Yorgunlar B, Mihmanlı V, Kılıçkaya A, On sekiz-yirmi dört gebelik haftaları arasında fetal humerus uzunluğu nomogramının araştırıması (thesis). Okmeydanı Eğitim ve Araştırma Hastanesi 1. Kadın Hastalıkları ve Doğum Kliniği, İstanbul; 2009.
7. Yolcu B. Popülasyonumuza ait fetal biyometrik ölçümlerin nomogramlarının belirlenmesi, Uzmanlık Tezi, İstanbul Bakırköy Doğumevi Kadın ve Çocuk Hastalıkları Eğitim Araştırma Hastanesi Kadın Hastalıkları ve Doğum Kliniği, İstanbul; 2005.

8. Mastrobattista JM, Pschirrer ER, Hamrick MA, Glaser AM, Schumacher V, Shirkey, BA, Hollier LM. Humerus length evaluation in different ethnic groups. J Ultrasound Med 2004;23:227-31.

9. Hadlock FP, Harris RB, Deter RL, Park SK. Fetal femur length as a predictor of menstrual age: sonographically measured. Am J Roentgenol 1982;138:875-8.

10. Chitty LS, Altman DG. Charts of fetal size: limb bones. BJOG: Int J Obstet Gynaecol 2002;109:919-29.

11. Ayangade SO, Okonofua FE. Normal growth of the fetal biparietal diameter in an African population. Int J Gynaecol Obstet 1986;24:35-42.

12. Muñoz WP, Moore PJ, MacKinnon A, Haines LM. Biparietal diameter and menstrual age in the black population attending Edendale Hospital. J Clin Ultrasound 1986;14:681-8.

13. Van Bogaert LJ. Customised gravidogram and fetal growth chart in a South African population. Int J Gynaecol Obstet 1999;66:129-36.

14. Hadlock FP, Harrist RB, Shah YP, Sharman RS, Park SK. Sonographic fetal growth standards. Are current data applicable to a racially mixed population? J Ultrasound Med 1990;9:157-60.

15. Mador ES, Ekwempu CC, Mutihir JT, Adoga GI, Ogunranti JO. Ultrasonographic biometry: Biparietal Diameter of Nigerian foetuses. Niger Med J 2011;52:41-4.

16. Chitty LS, Altman DG, Henderson A, Campbell S. Charts of fetal size: 4. Femur length. Br J Obstet Gynaecol 1994;101:132-5.

17. Chitty LS, Altman DG, Henderson A, Campbell S. Charts of fetal size: 3. Abdominal measurements. Br J Obstet Gynaecol 1994;101:125-31.

18. Chitty LS, Altman DG, Henderson A, Campbell S. Charts of fetal size: 2. Head measurements. Br J Obstet Gynaecol 1994;101:35-43.

19. Altman DG, Chitty LS. Charts of fetal size: 1. Methodology. $\mathrm{Br}$ J Obstet Gynaecol 1994;101:29-34.

20. Royston P, Wright EM. How to construct 'normal ranges' for fetal variables. Ultrasound Obstet Gynecol 1998;11:30-8.

21. Smellie W. Treatise on the Theory and Practice of Midwifery. In: McClintock AH, editor. Vol. 1. London: The New Syndenham Society; 1876. pp. 90-2.

22. Kankeow K. Charts of fetal biometries at Sukhothai Hospital. J Med Assoc Thai 2007;90:844-51.

23. Okupe RF, Coker OO, Gbajumo SA. Assessment of fetal biparietal diameter during normal pregnancy by ultrasound in Nigerian women. Br J Obstet Gynaecol 1984;91:629-32. 